NIH seek advice on Gallo

\section{Washington}

THE US National Institutes of Health (NIH) Office of Scientific Integrity last week made public that it was asking the National Academy of Sciences for advice in the preliminary stage of a 'fact-finding' inquiry into the conduct of National Cancer Institute researcher Robert Gallo.

Although details of the inquiry have not been revealed, Susanne Hadley, director of the Office of Scientific Integrity, says that the fact-finding process began last autumn. It was at this time that the Chicago Tribune newspaper published a 16-page supplement written by journalist John Crewdson on the famous dispute over the discovery of the AIDS virus. That dispute appeared to have been settled in 1987 when then President Ronald Reagan and French Prime Minister Jacques Chirac agreed to name Robert Gallo of the National Cancer Institute and Luc Montagnier of the Pasteur Institute as codiscoverers of the virus. But in his Chicago Tribune article, Crewdson alleges that the contribution of Gallo's laboratory could have involved an "an accident or a theft".

Hadley stresses that a formal NIH investigation of Gallo is not under way. The case, she says, is "in the inquiry stage right now . . . we are fact finding to see if an investigation is warranted." She says that NIH have asked the National Academy of Sciences to recommend a review panel but this does not mean that a formal investigation will necessarily follow. "We can assemble a panel for a number of other reasons", she says. NIH guidelines normally allow a 60 -day period between the beginning of a fact-finding inquiry and a decision whether or not to proceed with a formal investigation, although Hadley says the deadline may be extended in some circumstances.

The Office of Scientific Integrity normally will neither confirm nor deny that an inquiry or investigation is under way. But Hadley says that an exception was made in this case because of its significance "for NIH and biomedical research".

The publication of the Chicago Tribune supplement did not attract much attention in the scientific press or in US newspapers last autumn as many of its allegations were considered to be already well known. But the supplement did stimulate Congressman John Dingell, chairman of the oversight and investigations subcommittee that last year conducted several hearings into the case of Nobel-laureate David Baltimore, to write to William Raub, acting director of NIH (see Nature 343, 3; 4 January 1990)

Dingell asked whether NIH were going to look to look into the Chicago Tribune allegations and was not satisfied with
Raub's reply that a panel from Gallo's own institute, the National Cancer Institute, would be set up. A further exchange of letters followed in which Dingell made more specific demands.

It is not known if these letters pushed NIH's Office of Scientific Integrity into asking the National Academy for Sciences for advice, but Hadley points out that the fact-finding process had begun before Dingell first wrote to Raub.

Gallo has been hit hard by renewed interest in the allegations, according to an account of a telephone interview with National Cancer Institute director Samuel Broder, published in the 18 February issue of Out Week magazine.

In the interview, the substance of parts of which has been confirmed by the institute, Broder says that "Bob [Gallo] is being tied up in knots. I can't talk science with him. His mind is distracted and he can't focus on it".

Copies of the relevant page of Out Week, a small-circulation magazine providing strong support for homosexual rights, were sent by fax to several science journals and other media last week. It is not known who sent the fax messages or why, although whoever did so apparently took the precaution of deactivating the message line that identifies the sender's fax machine number. The copies were not sent by the magazine itself.

The Out Week article goes on to imply that Gallo is now under fire at the National Cancer Institute for lack of productivity.

But the author, Larry Kramer, who is frequently critical of the AIDS 'establishment', goes on to say that "For all his craziness... Gallo still knows more about AIDS than almost anyone around".

G. Christopher Anderson \& Alun Anderson

\title{
India opts for self-control
}

\section{New Delhi}

SAFETY guidelines for recombinant DNA research just released by the Department of Biotechnology seek to regulate genetic engineering research in India more by selfcontrol than by legal measures. Companies in countries such as West Germany where laws are strict may even find India's relaxed approach sufficiently attractive to shift some of their genetic engineering research to India.

The guidelines are the work of an 18member recombinant DNA advisory committee led by S. Varadarajan, an industrial chemist and former chief of the Council of Scientific and Industrial Research. Interestingly, issues relating to genetic engineering of human embryos, use of embryos and fetuses in research and human germ-line gene therapy are excluded from the scope of the guidelines.

Under the new rules, recombinant DNA work is classified into three categories depending on the perceived risk, and taking into account local factors such as immunity to diseases, laboratory environment and tropical conditions. Approval by the competent authority is needed only for such experiments as cloning of genes for toxins and for vaccine production, gene therapy and field release of altered organisms. Most recombinant DNA experiments need only notification and not approval.

S. Ramachandran, secretary of the Department of Biotechnology, says the guidelines were meant to make researchers aware of the need for good laboratory practice. Stringent laws, he feels, will stifle work in this important area where India is just beginning to make progress.
The guidelines are to be implemented by a three-tier mechanism, but the onus of ensuring safety rests mostly with an inhouse biosafety committee within the research institute itself.

Whether or not the institutions abide by the guidelines will be monitored by a Review Committee for Genetic Manipulation on the basis of surprise visits and bi-annual reports from the biosafety committees. Any violation, deliberate or due to negligence, will lead to cancellation of research grants - a threat of no consequence to private companies, Indian or foreign, which do not depend on government funds.

Legal action will be taken only in case of violations in regard to field release of engineered organisms or products. Such releases must have the approval of a genetic engineering approval committee to be set up under the Department of Environment. It will be a statutory body with "judicial powers to inspect, investigate and take punitive action" under the Environmental Protection Act, the same act that deals with air and water polluters. The act has not been successful in controlling industrial pollution because it contains many loopholes and imposes few sanctions.

Whether self-control is good enough to regulate recombinant DNA technology remains to be seen. According to Ramachandran, some 26 institutions have set up biosafety committees and others have been asked to fall in line. He admits the new rules are not fool-proof but is confident that deliberate violations of the guidelines cannot remain undetected for long.

K. S. Jayaraman 